\title{
PENTINGNYA KEMAMPUAN SELF-EFFICACY MATEMATIS SERTA BERPIKIR KRITIS PADA PEMBELAJARAN DARING MATEMATIKA
}

\author{
Oleh :
}

*Siti Nur Afifah ${ }^{1)}$, Anggun Badu Kusuma ${ }^{2)}$

Fakultas Keguruan dan Ilmu Pendidikan, Universitas Muhammadiyah Purwokerto ${ }^{1,2)}$ Email: siti.nurafifah2600@gmail.com ${ }^{1)}$, anggun.badu@ gmail.com ${ }^{2)}$

\begin{abstract}
Abstrak
Self-efficacy matematis merupakan keyakinan seseorang dalam menyelesaikan permasalahan matematika dan berpikir kritis merupakan kemampuan berpikir yang konstruktif dalam mencari solusi. Penelitian ini bertujuan untuk mengkaji pentingnya kemampuan berpikir kritis serta self efficacy matematis pada pembelajaran daring matematika. Metode yang digunakan dalam penelitian ini adalah metode kajian pustaka yang dilakukan dengan cara mengkaji informasi dari buku, artikel atau penelitian sebelumnya yang relevan. Penelitian ini dilatarbelakangi oleh pembelajaran di masa pandemi yang menuntut siwa untuk belajar dirumah masing-masing, sehingga menyebabkan tantangan baru dan menurunya beberapa aspek. Aspek tersebut dapat dilihat dari self efficacy matematis dan kemampuan berpikir kritis. Kesimpulannya, siswa yang memiliki self efficacy matematis mampu menciptakan motivasi dan kemandirian belajarnya sendiri. Hal ini dapat meningkatkan aspek afektif dan psikologi siswa. Lalu, siswa yang memiliki kemampuan berpikir kritis akan mudah menganalisis masalah, meracang solusi, mengevaluasi serta menyimpulkan hasilnya sehingga dapat menigkatkan kemampuaan kognitif. Penelitian ini penting guna memaksimalkan siswa dalam belajar matematika secara daring.
\end{abstract}

Kata Kunci-Self-efficacy matematis, kemampuan berpikir kritis, pembelajaran daring

\section{Abstract}

Self-efficacy mathematics is a person's belief in solving mathematical problems, and critical thinking is the ability to think constructively in finding solutions. This study examines the importance of critical thinking skills and mathematical self-efficacy in mathematics online learning. The method used in this research is the literature review method which is carried out by reviewing information from relevant books, articles or previous research. This research is motivated by learning during the pandemic, which requires students to study in their respective homes, which causes new challenges and decreases in several aspects. This aspect is related to mathematical self-efficacy and critical thinking skills.In conclusion, students who have mathematical self-efficacy can create their motivation and learning independence. It can improve the affective and psychological aspects of students. Then, students who have critical thinking skills will quickly analyze problems, design solutions, evaluate and conclude the results to increase their cognitive abilities. This research is essential to maximize students learning mathematics online.

Keywords—self-efficacy mathematics, critical thinking skills, online learning

\section{PENDahuluan}

Dunia sedang digemparkan oleh wabah Covid-19 yang mana wabah tersebut juga menyerang Indonesia. Adanya Covid-19 tidak hanya berdampak pada dunia kesehatan tetapi juga pada dunia pendidikan. Pembelajaran pada masa Covid-19 mengharuskan pembelajaran tanpa tatap muka atau Study From Home. Hal ini diperkuat oleh penuturan Luh, et al. bahwa pembelajaran dirumah dengan fasilitas penunjang menjadi solusi (Herliandry, et al., 2020). Pembelajaran tanpa tatap muka dapat dilakukan secara daring atau online. Pembelajaran daring merupakan pembelajaran dengan memanfaatkan platform yang mendukung proses belajar (Handayani, 2020). Pembelajaran bisa memanfaatkan platform online seperti grup whatsapp, google classroom, schoology, etmodo, dan sebagainya.

Dalam belajar daring, baik guru maupun siswa perlu melakukan penyesuaian. Hal itu terjadi karena belajar daring merupakan suatu kebiasaan baru bagi sistem pendidikan di Indonesia. Akibatnya dari hal tersebut tentunya menimbulkan tantangan termasuk kesulitan belajar bagi siswa. Kesulitan belajar merupakan ketidakmampuan siswa dalam memahami konsep, prinsip dan keterampilan baik ditinjau dari faktor internal maupun eksternal (Hadiprasetyo, 2020).

Berdasarkan penelitian terhadap 30 siswa SMA diketahui bahwa kesulitan belajar daring matematika mencapai 75\% (Utami, et al., 2020). Faktor yang memengaruhi hal tersebut adalah kendala signal serta kurang ada pemahaman terhadap belajar online dan kurangnya interaksi, tugas yang terlalu 
banyak serta bahan ajar yang kurang memadai. Lalu pada hasil penelitian terhadap 51 siswa SMP diketahui bahwa kesulitan belajar daring matematika disebabkan oleh 1) keterbatasan ruang interaksi antara guru dan siswa, 2) terlalu banyak rumus, 3) objek yang dipelajari berupa pola abstrak (Fauzy \& Nurfauziah, 2021). Hal tersebut menyebabkan siswa kesulitan dalam memahami materi matematika yang diajarkan dan mudah menyerah ketika menghadapi soal atau masalah matematika yang sulit.

Matematika merupakan suatu ilmu pengetahuan dasar yang penting untuk dipelajari pada setiap jenjang pendidikan mulai dari taman kanak - kanak hingga sekolah menengah bahkan perguruan tinggi. Hal ini selaras dengan apa yang diungkapkan Nicky, ia mengatakan bahwa matematika adalah ilmu pengetahuan yang dipelajari di sekolah (Puspaningtyas, 2019). Menurut Ufi, Helti \& Danang, matematika merupakan ilmu yang penting (Dwidarti, et al., 2019). Akan tetapi seringkali matematika masih diangap sebagai pelajaran yang sulit dan kurang disukai bahkan menakutkan bagi sebagian banyak siswa. Hal itu dikarenakan di dalam matematika memuat banyak rumus, definisi serta berbagai jenis soal sehingga siswa merasa tidak yakin, cemas dan kesulitan dalam menyelesaikan masalah matematika.

Belajar matematika tidak hanya berkaitan dengan angka saja, tetapi juga memuat berbagai kemampuan yang dapat dikembangkan dan bermanfaat pada kehidupan sehari - hari. Kemampuan tersebut antara lain berpikir logis, berpikir kritis, sistematis dan kreatif (Ulfa, 2019). Untuk menghadapi tantangan pada masa yang akan datang, kemampuan berfikir kritis sangat diperlukan. Berpikir kritis berkaitan dengan pola pikir seseorang dalam pemecahan masalah. Selain berpikir kritis, pemecahan masalah matematika dapat diselesaikan dengan kemampuan afektif yaitu self-efficacy matematis (Indahsari, et al., 2019). Maka dari itu untuk menyelesaikan permasalahan matematika, kemampuan berpikir kritis dan self-efficacy matematis sangat diperlukan. Karena, soal atau masalah matematika erat kaitannya dengan proses yang runtun dan sistematis untuk memperoleh hasil yang baik dan benar.

Kemampuan di bidang matematika yang diperoleh siswa Indonesia menurut hasil studi OECD (2018) dalam PISA 2018 berada pada level 1. Yang mana Indonesia berada di peringkat 72 dari 78 negara dengan skor rata-rata 379 dari skor rata-rata internasional yaitu 487 (Schleicher, 2019). Hal ini menujukan bahwa kemampuan matematika siswa di indonesia masih sangat rendah di bawah rata-rata internasional. Disamping kemampuan matematika yang rendah, indonesia juga menduduki peringkat 10 besar dari bawah untuk minat membaca dan sains.

Sementara itu berdasarkan hasil studi TIMSS (2015) (Trends in International Mathematics and Science Study), kemampuan matematis siswa di Indonesia masih jauh di bawah rata-rata internasiaonal. Skor rata-rata Indonesia adalah 397 dari skor rata-rata internasional 500. Yang mana skor tersebut berada pada peringkat 44 dari 49 negara di dunia. TIMSS merupakan studi terkait matematika dan ilmu pengetahuan yang diselenggarakan oleh Asosiasi Internasional untuk Evaluasi Prestasi Pendidikan (IEA) (Thomson, et al., 2017).

Rendahnya skor TIMSS dan PISA di Indonesia disebabkan karena soal TIMSS dan PISA mempunyai tingkat kesulitan yang tinggi. Hal ini menandakan kemampuan matematis siswa di Indonesia masih rendah. Penyebabnya karena rendahnya kepercayaan diri siswa, sikap positif terhadap matematika, serta kemampuan pemecahan masalah yang berkaitan erat dengan kemampuan berpikir kritis. (Prastyo, 2020) (Hadi \& Novaliyosi, 2019) (Nursyahidah \& Albab, 2017).

Dalam penyelesaian masalah matematis, siswa tidak cukup hanya memiliki kemampuan kognitif saja tetapi juga mempunya sikap percaya diri akan kemampuannya dalam proses pemecahan masalah. Selfefficacy adalah keyakinan diri siswa dalam menyelesaikan masalah matematis (Alifia \& Rakhmawati, 2018). Self-efficacy atau efikasi diri merupakan kepercayaan yang ada dalam diri seseorang untuk menemukan, menyusun, dan menjalankan suatu tugas sehingga tujuannya bisa tercapai. Rasa kepercayaan diri berguna dalam menghadapi masalah di kehidupan sehari-hari. Dengan kemampuan self-efficacy, siswa lebih mudah dalam menyelesaikan masalah atau tugas yang diberikan bahkan dapat meningkatkan prestasi belajar. Hal ini didukung oleh pernyataan Muhammad yaitu keberhasilan siswa dalam menyelesaikan masalah dapat pengengaruhi oleh kemampuan self-efficacy (Jatisunda, 2017).

Dalam pelajaran matematika seringkali siswa menemui banyak jenis soal matematika. Mulai dari tingkat kesulitan yang rendah sampai tingkat tinggi. Dalam pemecahan soal, siswa dituntut untuk memiliki rasa percaya bahwa dirinya mampu untuk menyelesaian soal yang diberikan. Siswa dengan kemampuan self-efficacy tinggi akan lebih fokus pada menemukan solusi permasalahan daripada berpikir tentang kekurangan yang ada pada dirinya. Hal ini dperkuat oleh Pahrul, Benny \& Muhammad yaitu pengambilan keputusan dan tindakan penyelesaian masalah dipengaruhi oleh self-efficacy (Arifin, dkk, 2017). Tresnawati, Wahyu \& Euis, juga menuturkan bahwa siswa yang memiliki self-efficacy matematis memiliki keberanian dan banyak ide dalam menentukan langkah penyelesaian masalah (Tresnawati, Hidayat, \& Rohaeti, 2017). 
Penerapan pembelajaran daring tentu saja menjadi pengalaman dan kebiasaan baru bagi siswa yaitu siswa dituntut untuk belajar dirumah masing-masing. Hal ini membuat tingkat keinginan terus belajar, sifat mandiri dan dukungan keluarga berpengaruh dalam hasil pembelajaran (Sari, 2020). Terlebih lagi kurangnya interaksi dengan lingkungan sekolah dapat membuat siswa kesulitan mendapat motivasi belajar. Seseorang yang mempunyai self-efficacy matematis yang tinggi akan mudah menciptakan motivasi belajar, percaya akan kemampuannya, tidak mudah menyerah dalam mencari solusi serta mampu mengontrol dan mengembangkan usahanya dalam kondisi yang menjadi tantangan seperti belajar daring.

Berpikir kritis adalah termasukin kemampuan berpikir tingkat tinggi atau High Order Thinking. Seperti yang digagas oleh dan bahwa Berpikir kritis adalah kemampuan menganalisis, memanipulasi dan mengevaluasi materi yang sudah dipelajari dalam mengambil keputusan pada suatu permasalahan (Suharna \& Abdullah, 2020) (Hartini, Misri \& Nursuprianah, 2018). Maka dari itu, kemampuan berpikir kritis sangat penting pada kehidupan sehiri - hari.

Menyelesaikan soal matematika seringkali identik dengan banyak cara atau langkah. Banyaknya cara dan kompleksitas pada soal matematika menuntut siswa untuk mempunyai kemampuan berpikir kritis. Maka dari itu, matematika dan berpikir kritis saling berkaitan. Pada penelitian oleh Purnama, M. Ikhsan \& Muhammad, siswa yang memiliki kemampuan berpikir kritis tinggi akan lebih cermat serta teliti dalam menganalisis soal, mengidentifikasi informasi dan merumuskan perhitungan sehingga mendapat kesimpulan yang tepat dari masalah yang disajikan (Farib, Ikhsan \& Subianto, 2019).

Kemampuan berpikir kritis dalam proses pembelajaran daring matematika sangat diperlukan. Siswa yang memiliki kemampuan berpikir kritis akan mudah dalam menyelesaikan permasalahan yang diberikan. Siswa dapat menganalisis soal, merencanakan langkah yang diambil, menyimpulkan dan mengevaluasi. Hal ini penting karena saat pembelajaran daring, sering terjadi kurangnya interaksi antara guru dan siswa, siswa malu untuk bertanya dan siswa diberi banyak tugas.

Perbedaan artikel ini dengan artikel yang terdahulu adalah dalam artikel ini lebih mengkaji dan memperdalam kebutuhan kemampuan self-efficacy matematis dan berpikir kritis dalam proses pembelajaran daring matematika. Harapannya artikel ini dapat memotivasi untuk meningkatkan kemampuan self-efficacy matematis dan berpikir kritis supaya hasil belajar matematika pada masa pandemi dapat maksimal. Dengan demikian, tujuan penulisan artikel ini adalah untuk mengakaji pentingnya kemampuan self-efficacy matematis dan berpikir kritis siswa dalam proses pembelajaran pada masa pandemi yaitu pembelajaran daring.

\section{METODE PENELITIAN}

Penelitian ini menggunakan jenis penelitian kajian pustaka. Penelitian kajian pustaka (Kepustakaan) dilakukan dengan cara mengumpulkan informasi baik berupa buku, hasil penelitian, artikel, catatan, dan jurnal yang berkaitan (Sari, M, 2020). Teknik analisis data dilakukan penulis dengan cara mencari referensi terkait berpikir kritis, self-efficacy matematis dan pembelajaran matematika pada masa pandemi. Penulis mengkaji hasil pemikiran, gagasan, hasil penelitian maupun temuan lainnya yang berkaitan dengan kemamuan berpikir kritis, self-efficacy matematis dan pembelajaran matematika pada masa pandemi.

\section{HASIL DAN PEMBAHASAN}

Wabah covid-19 merupakan wabah yang cukup mengagetkan bagi semua orang. Setelah Covid19 memasuki Indonesia dan jumlah pasien terinfeksi terus bertambah, maka pemerintah memberlakukan social distancing guna mengurangi penyebaran virus Covid--19. Presiden Jokowi menuturkan bahwa social distancing adalah salah satu solusi untuk menghambat penularan virus Covid-19 (Irwan \& Santaria, 2020). Tentunya social distancing tidak hanya berdampak pada dunia kesehatan saja tetapi juga pada dunia pendidikan. Mulai pertengahan Maret 2020, pemerintah menginstruksikan untuk menyelenggarakan Study From Home atau pembelajaran dirumah masing-masing. Pemberlakuan Study From Home tentunya menjadikan siswa tidak dapat melakukan kegiatan tatap muka di dalam kelas bersama guru. Permbelajaran jarak jauh atau daring harus didukung dengan adanya koneksi internat dan dibantu dengan platform pembelajaran online. Platform tersebut seperti whatsapp grup, google classroom, google meet, zoom, etmodo dan sebagainya.

Pembelajaran daring memberikan bebera tantangan yaitu (1) sistem pembelajaran belum siap (2) susahnya jaringan internet (3) fasilitas penunjang yang belum memadai (4) orang tua dituntut menjadi guru untuk anak-anaknya (5) informasi dan pesan kurang dapat tersampaikan (Suharna \& Abdullah, 2020). Hal tersebut tentunya menimbulkan adanya keterbatasan interaksi pengajaran dan emosional antara siswa dan guru yang menyebabkan terkendalanya penyampaian dan pemahaman materi matematika. 
Gita, Chatarina \& Ari menuturkan bahwa kebanyakan siswa mengeluh dan kurang efektif dengan pembelajaran jarak jauh (Kencanawaty, Febriyanti \& Irawan, 2020). Secara psikologi, pembelajaran yang dilakukan di rumah sangat berbeda denga proses belajar mengajar di sekolah (Suharna \& Abdullah, 2020). Sementara itu berdasarkan penemuan Khairul terdapat beberapa guru yang merasa pembelajaran daring kurang efektif dibanding kegiatan belajar tatap muka di kelas (Husna, K.., 2020).

Dalam belajar matematika perlu pemahaman yang lebih karena didalamnya memuat banyak rumus dan objek-objek abstrak. Ditambah dengan kurangnya interaksi antara siswa dan guru menyebabkan siswa kesulitan dalam memahami materi matematika. Terlebih lagi jika guru memberian tugas yang banyak dan soal yang sulit. Hal tersebut membuat siswa mudah menyerah serta akan berpengaruh terhadap hasil belajar.

Dalam penelitian di SMP Negeri Sokoria menyebutkan bahwa pembelajaran daring matematika dilakukan dengan memberikan ringkasan materi atau modul kepada siswa, guru tidak bisa sepenuhnya memantau proses kegiatan belajar siswa dan kegiatan tanya jawab teralihkan dengan pemberian tugas, hal ini menyebabkan siswa kesulitan dalam menyerap materi serta memahami materi matematika (Wilfridus, Tupen \& Mei, 2021). Pemberian tugas yang banyak baik dari mata pelajaran matematika maupun mata pelajaran lain menyebabkan tugas siswa menumpuk. Hal ini menyebabkan banyak siswa mengeluh hingga stres (Mahmudah, 2020). Sehingga Pembelajaran daring berpengaruh terhadap aspek kognitif, afektif dan psikologi siswa. Maka dari itu, solusi dari permasalah tersebut adalah dengan menanamkan kemampuan berpikir kritis dan self-efficacy matematis.

Kemampuan berpikir kritis erat kaitannya dengan kemampuan pemecahan masalah, merencanakan langkah yang akan diambil dan mengevaluasi solusi yang telah didapat. Dengan Kemampuan tersebut dapat dilatih dengan kemampuan efikasi diri (Riyanto, Waluya, \& Mariani, 2019). Siswa yang mempunyai kemampuan self-efficacy yang tinggi akan percaya dengan kemampuannya dalam menyelesaikan tugas atau permasalahan yang diberikan sehingga siswa dapat bertindak cepat untuk merencanakan solusi permasalahan matematika. Terlebih pada pembelajaran daring matematika, siswa dituntut untuk memiliki pola kemandirian belajar dan hal ini dapat dipengaruhi oleh kemampuan selfefficacy. Siswa yang mempunyai keingintahuan rendah maka menimbulkan kesulitan mengikuti pembelajaran matematika karena minimnya penguasaan materi (Wilfridus, Tupen \& Mei, 2021).

Pelaksanaan program Study From Home atau belajar di rumah sebagai solusi pencegahan penyebaran virus covid-19 menuntut siswa untuk membiasakan kemandirian belajar. Salah satu mata pelajaran yang menjadi tantangan dan dianggap sulit oleh siswa dalah matematika. Hal tersebut dikarenakan karakteristik matematika adalah memuat konsep-konsep, banyak rumus dan penyelesaian yang sistematis. Dalam belajar mandiri dirumah, siswa harus dapat merancang dan menyusun strategi belajar, memandang masalah sebagai tantangan, memanfaatkan sumber belajar dengan baik, mampu bekerjasama secara individu maupun kelompok, mengevaluasi usaha yang telah dilakukan serta mengontrol diri. Namun masih banyak siswa kesulitan dalam membangun kemandirian belajar. Kemandirian belajar dipengaruhi oleh faktor internal yaitu self-efficacy, motivasi belajar, sikap, minat dan kebiasaan belajar (Sulaiman \& Purwoko, 2021).

Self-efficacy matematis adalah sikap kepercayaan diri atau keyakinan seseorang dalam merancang, menyusun dan mencari solusi dari permasalahan matematika. self-efficacy matematis memiliki pengaruh positif terhadap proses pembelajaran matematika terlebih dalam menghadapi tantangan baru dalam pembelajaran daring. Bandura (Alifia \& Rakhmawati, 2018) menyebutkan bahwa terdapat tiga dimensi self-efficacy yang digunakan dalam mengukur kemampuan self-efficacy seseorang yaitu :

1. Magnitude/Level

Magnitude/Level berkaitan dengan derajat kesukaran tugas yang diyakini mampu dikerjakan oleh suatu individu. Apabila individu tersebut dihadapkan pada tugas-tugas yang disusun berdasarkan tingkat kesukarannya, maka kemampuan self-efficacy dari individu sebatas pada tugas yang mudah, sedang dan sulit. Dimensi ini mempunyai pengaruh terhadap tindakan yang dipilih individu dalam menyelesaikan tugas yaitu tindakan yang akan dicoba atau dihindari.

2. Strenght

Strenght berkaitan dengan tingkat kekuatan dari kemampuan self-efficacy individu terhadap keyakinan dalam kemampuannya. Ketika dihadapkan dengan tugas yang sulit, individu yang mempunyai selfefficacy yang kuat akan tidak mudah menyerah, ulet dan selalu berusaha untuk meningkatkan usahanya dalam menyelesaikan tugas dengan baik. Sebaliknya, individu yang kemampuan self-efficacy yang lemah akan mudah terpengaruh oleh rintangan-rintangan dalam menyelesaikan tugasnya sehingga menyebababkan ia cederung mudah menyerah. 


\section{Generality}

Generality berkaitan dengan kemampuan individu dalam menggeneralisasikan tugas-tugas yang telah ia lakukan, seperti apakah ia menganggap suatu tugas sebagai hambatan atau suatu tantangan. Dimensi ini dinilai baik apabila individu memiliki keyakinan terhadap kemampuannya sebatas pada tugas tertentu atau pada seluruh tugas.

Berdasarkan dimensi diatas jika dikaitkan dengan matematika maka individu yang sudah mengusai self-efficacy akan memiliki keyakinan pada kemampuan dirinya serta ketertarikan dalam mempelajari materi, menyelesaikan soal-soal dan tugas matematika. Semakin tinggi kemampuan selfefficacy siswa, maka semakin tinggi pula keyakinan dan semangat terhadap dirinya dalam menyelesaikan permasalah matematika. Siswa yang memiliki kemampuan self-efficacy yang rendah cenderung mudah menyerah ketika dihadapi permasalahan matematika yang ia anggap sulit.

Pemberian tugas yang banyak serta kurangnya pemahaman siswa terhadap materi matematika saat pembelajaran daring, menimbulkan siswa yang memiliki self-efficacy rendah akan menghindari tugas yang sulit dan mudah goyah semangatnya. Sedangkan siswa yang memiliki self-efficacy tinggi akan lebih semangat, tekun, ulet, serta berusaha semaksimal mungkin untuk menyelesaikan tugas yang diberikan. Rendahnya self-efficacy matematis siswa dalam menyelesaikan soal matematika disebabkan salah satunya karena kemampuan pemecahan masalah siswa masih rendah pula. Guru seringkali memberikan soal non rutin sehingga siswa terbiasa dengan menghafal rumus bukan memahami konsep. Hal ini menyebabkan siswa kesulitan menghubungkan informasi yang terdapat pada soal kedalam konsep matematika yang sesuai untuk menyelesaikan permasalahan. Siswa menjadi tidak yakin pula dengan kemampuannya jika mendapati soal yang berbeda dari contoh yang diberikan. Namun pada kondisi tersebut, tidak sedikit siswa menunjukkan sikap malu untuk bertanya kepada guru sehingga berdampak pula pada rendahnya kemampuan self-efficacy. Akibatnya keberhasilan siswa dalam belajar matematika tidak maksimal.

Manfaat self-efficacy matematis terhadap keberhasilan belajar daring matematika adalah untuk mengontrol motivasi belajar matematika. Ketika siswa stres dan emosi saat mendapati kendala seperti susah koneksi internet, terbebani dengan banyak tugas, kurang memahami materi, bosan dan lelah maka akan memicu menurunnya self-efficacy. Tuntutan bagi siswa ketika pembelajaran daring terutama pelajaran matematika adalah siswa harus memiliki kesadaran untuk belajar secara berkesinambungan, mempunyai daya juang menyelesaikan tugas, konsentrasi, sadar akan tanggung jawab belajar, mencari sumber-sumber belajar dan aktif bertanya ketika mendapati persoalan yang belum dipahami. Kurangnya motivasi belajar siswa disebabkan karena kurangnya perhatian siswa dalam proses belajar mengajar, lalai dan menunda mengerjakan tugas atau ujian, serta membolos (Suryaningsih \& Rahim, 2019).

Self-efficacy matematis memungkinkan siswa untuk sadar pentingnya matematika dalam kehidupan sehari-hari, percaya diri dan merasa senang ketika dihadapkan dengan persoalan matematika yang menantang. Siswa yang memiliki self-efficacy matematis yang tinggi akan mengerjakan tugasnya dengan tenang, dapat bertahan untuk berpikir dan usaha mencari solusi sehingga menciptakan rasa bersungguh-sungguh, ulet dan mengontrol emosi. Sebaliknya, siswa yang memiliki self-efficacy rendah cenderung tidak yakin terhadap kemampuannya yang menyebabkan ia bergantung dengan jawaban temannya. Self-efficacy perlu dikembangkan oleh siswa supaya dapat menerapkan pembelajaran matematika pada kehidupan sehari-hari, sehingga proses pembelajaran dapat optimal (Lusiana \& Setyaningsih, 2020). Oleh karena itu, kemampuan self-efficacy matematis menjadi salah satu faktor penting dalam mencapai keberhasilan maksimal pembelajaran daring matematika.

Keberhasilan tersebut dapat pula dicapai dengan aspek kognitif yang mana dibutuhkan dalam kemampuan pemecahan masalah. Aspek kognitif mencakup hubungan siswa dalam memahami masalah secara bertahap (Anugrahana, 2021). Ketika pembelajaran daring, seringkali siswa mendapat banyak kendala baik jaringan internet maupun pemahaman materi. Hal tersebut menimbulkan rasa cemas pada diri siswa (Mulyana, Senajaya \& Ismunandar, 2021). Saat ini masih banyak siswa yang merasa pembelajaran tatap muka lebih memudahkan dalam memahami materi matematika. Hal ini dikarenakan siswa kesulitan dalam menerapkan konsep, rumus, menganalisis, mengevaluasi serta menarik kesimpulan (Koto \& Priyanda, 2021).

Pelaksanaan pembelajaran daring merupakan bentuk implikasi dari revolusi 4.0. Untuk menghadapi perkembangan revolusi 4.0, pendidkan saat ini perlu menerapkan pembelajaran abad 21 . Keterampilan yang perlu dikuasai adalah keterampilan 4C. Kemampuan tersebut terdiri dari keterampilan kolaborasi, berpikir kritis dan berpikir kreatif. Salah satu keterampilan yang sangat penting adalah kemampuan berpikir kritis. Kemampuan tersebut penting karena membangun sikap bijak dalam menghadapi permasalahan dalam kehidupan mereka (Prasojo \& Ariyanti, 2017). 
Berpikir kritis adalah kemampuan seseorang dalam berpendapat, mengevaluasi pendapat pribadi dan orang lain, kemampuan dasar, dan keingingan menggali pemahaman untuk menarik kesimpulan (Handayani, 2020). Karim \& Normaya mengungkapkan bahwa ada 4 indikator berpikir kritis yaitu sebagai berikut (Rahayu \& Alyani, 2020) :

1. Interpretasi

Indikator ini berkaitan dengan kemampuan individu dalam memahami masalah, yang mana hal ini ditunjukan dengan merumuskan pokok-pokok permasalahan, seperti apa yang diketahui maupun yang ditanya dalam soal.

2. Analisis

Indikator ini berkaitan dengan kemampuan menghubungkan antara pertanyaan dan konsep serta mengungkap fakta yang ada dalam soal yang diberikan.

3. Evaluasi

Indikator ini berkaitan dengan kemampuan menyusun dan melaksanakan strategi dalam menyelesaikan tugas yang diberikan secara tepat.

4. Inferensi

Indikator ini berkaitan dengan kemampuan dalam menarik kesimpulan dari persoalan yang dikerjakan.

Dari indikator diatas jika dikaitkan dengan matematika, siswa yang memiliki kemampuan berpikir kritis akan terbantu dalam memecahkan masalah matematika yang menuntut siswa untuk mampu merumuskan, menafsirkan permasalahan, sehingga siswa dapat menyusun strategi yang tepat terhadap permasalahan serta menarik kesimpulan.. Dalam tuntutan belajar mandiri, siswa yang memiliki kemampuan berikir kritis tinggi dapat mempertimbangkan informasi yang didapat, merumuskan pertanyaan, mengidentifikasi dan menganalisis permasalahan serta memberi alasan terhadap keputusan yang ia ambil. Kemampuan ini penting dimiliki siswa dalam pembelajaran daring karena akan memudahkan komunikasi antar siswa dan guru dapat berjalan dengan baik dan sistematis sehingga pemerolehan informasi dapat diterima dan dipahami secara maksimal. Dengan demikian kemampuan berpikir kritis berpengaruh positif serta membangun karakter siswa. Hal ini menciptakan siswa lebih fokus dan maksimal dalam mencapai keberhasilan dalam belajar.

Kemampuan berpikir kritis melatih seseorang untuk lebih memahami konsep daripada hanya mengingat. Dalam belajar matematika, siswa diharapkan mampu menerapkan konsep, rumus, teorema, merancang solusi, menganalisis, mengevaluasi dan menyimpulkan soal yang diberikan. Namun, ketika siswa merasa kurang efektif dalam belajar secara daring akan menimbulkan tidak berkembangnya kemampuan berpikir kritis. Siswa yang mempunyai kemampuan berpikir kritis rendah cenderung hanya mampu mengidentifikasi soal yang sesuai fakta saja (Koto \& Priyanda, 2021).

Siswa yang memiliki kemampuan berpikir kritis yang tinggi lebih peka terhadap permasalahan yang ada sehingga mampu memilah informasi dengan baik. Ketika siswa dihadapkan dengan soal matematika yang sulit maka kemampuan berpikir kritis sangat dibutuhkan dalam menganalisis dan berpikir logis (Nurazizah \& Nurjaman, 2018). Siswa mampu berpikir tingkat tinggi dalam menyelesaikan permasalahan matematika baik bersifat rutin maupun non rutin yaitu permasalahan dikehidupan sehari-hari. Sehingga kemampuan berpikir kritis menjadi penting dan berpengaruh positif terhdap prestasi belajar siswa.

\section{KESIMPULAN}

\section{Kesimpulan}

Self-efficacy penting dalam pembelajaran daring matematika karena self-efficacy dapat membangun motivasi serta kemandirian belajar, aspek afektif dan psikologi siswa. Berpikir kritis penting dimiliki siswa dalam pembelajaran daring matematika karena membantu siswa dalam memahami materi, menyelesaikan masalah matematika baik ketika ia kekurangan informasi materi yang guru sampaikan serta meningkatkan aspek kognitif.

\section{Saran}

1. Kepada Guru khususnya Guru matematika, dapat merancang metode pembelajaran dan strategi belajar yang menciptakan keefektifan pembelajaran daring matematika sehingga siswa mudah memahami materi serta tercapai tujuan pembelajarannya.

2. Kepada Siswa, diharapkan memahami pentingnya self-efficacy dan berpikir kritis dalam pembelajaran matematika dengan terus melatih kemampuan memecahkan masalah matematika.

3. Kepada Pembaca, diharapkan dapat menyadarkan akan pentingnya self-efficacy dan berpikir kritis serta menjadi bahan bacaan dan acuan bagi penelitian berikutnya. 


\section{REFERENSI}

Alifia, N. N., \& Rakhmawati, I. A. (2018). Kajian kemampuan self-efficacy matematis siswa dalam pemecahan masalah. Jurnal Elektronik Pembelajaran Matematika, 05(1), 44-54.

Anugrahana, A. (2021). Analisis Kemampuan Pemahaman Kognitif Dan Kesulitan Belajar Matematika Konsep "Logika" Dengan Model Pembelajaran Daring. Scholaria: Jurnal Pendidikan Dan Kebudayaan, 11(1), 37-46. https://doi.org/10.24246/j.js.2021.v11.i1.p37-46

Arifin, P., Trisna, B. N., \& Atsnan, M. F. (2017). MENGEMBANGKAN SELF-EFFICACY MATEMATIKA MELALUI PEMBELAJARAN PENDEKATAN MATEMATIKA REALISTIK PADA SISWA KELAS VII D SMP NEGERI 27 BANJARMASIN TAHUN PELAJARAN 20162017, 3(2), 93-104.

Dwidarti, U., Mampouw, H. L., \& Setyadi, D. (2019). Analisis Kesulitan Siswa dalam Menyelesaikan Soal Cerita pada Materi Himpunan. Jurnal Cendekia : Jurnal Pendidikan Matematika, 3(2), 315-322. https://doi.org/10.31004/cendekia.v3i2.110

Farib, P. M., Ikhsan, M., \& Subianto, M. (2019). Proses berpikir kritis matematis siswa sekolah menengah pertama melalui discovery learning. Jurnal Riset Pendidikan Matematika, 6(1), 99-117. https://doi.org/10.21831/jrpm.v6i1.21396

Fauzy, A., \& Nurfauziah, P. (2021). Kesulitan Pembelajaran Daring Matematika Pada Masa Pandemi COVID- 19 di SMP Muslimin Cililin, 05(01), 551-561.

Hadiprasetyo, K., Exacta, A. P., \& Maharani, A. (2020). Matematika Dengan Pembelajaran Dalam Jaringan ( Daring ) Selama Masa Darurat Covid-19 Pada Siswa Kelas Viii Smp Negeri 2 Ngadirojo Tahun Ajaran 2019 / 2020. Jurnal Pendidikan, Sains, Sosial Dan Agama, VI, 6-12.

Hadi, S., \& Novaliyosi. (2019). TIMSS Indonesia (Trends in International Mathematics and Science Study). Prosiding Seminar Nasional \& Call For Papers Program Studi Magister Pendidikan Matematika Universitas Siliwangi, 562-569.

Handarini, O. I., \& Wulandari, S. S. (2020). Pembelajaran Daring Sebagai Upaya Study From Home (SFH) Selama Pandemi Covid 19. Jurnal Pendidikan Administrasi Perkantoran (JPAP), 8(3), 496-503.

Handayani, F. (2020). Membangun Keterampilan Berpikir Kritis Siswa Melalui Literasi Digital Berbasis STEM pada Masa Pandemik Covid 19. CENDEKIAWAN, 2(2), 69-72.

Hartini, T., Misri, M. A., \& Nursuprianah, I. (2018). Pemetaan Kemampuan Hots Siswa Berdasarkan Standar Pisa Dan Timss Untuk Meningkatkan Mutu Pendidikan. Eduma: Mathematics Education Learning and Teaching, 7(1), 83-92. https://doi.org/10.24235/eduma.v7i1.2795

Herliandry, L. D., Nurhasanah, N., Suban, M. E., \& Kuswanto, H. (2020). Pembelajaran Pada Masa Pandemi Covid-19. JTP - Jurnal Teknologi Pendidikan, 22(1), 65-70. https://doi.org/10.21009/jtp.v22i1.15286

Husna, K. (2020). PROSES PEMBELAJARAN MATEMATIKA DI MADRASAH IBTIDAIYAH NEGERI 3 LANGSA DI TENGAH PANDEMI COVID-19. Pedagogik: Jurnal Ilmiah Pendidikan dan Pembelajaran Fakultas Tarbiyah Universitas Muhammadiyah Aceh, 7(2, Oktober), 144-155.

Indahsari, I. N., Situmorang, J. C., \& Amelia, R. (2019). Analisis kemampuan pemecahan masalah matematis dan self efficacy siswa MAN. Journal On Education, 01(02), 256-264.

Jatisunda, M. G. (2017). Hubungan self-efficacy siswa SMP dengan kemampuan pemecahan masalah matematis. Jurnal Theorems (The Original Research of Mathematics), 1(2), 24-30.

Kencanawaty, G., Febriyanti, C., \& Irawan, A. (2020). Tantangan dan Strategi Pembelajaran Matematika di Masa Adaptasi Kebiasaan Baru (AKB) Dampak dari Covid-19. Diskusi Panel Nasional Pendidikan Matematika.

Koto, M. J., \& Priyanda, R. (2021). Analisis Kemampuan Critical Thinking Matematis Siswa dalam Penggunaan Perangkat Pembelajaran Berbasis Virtual Di SMA Negeri 3 Bangko Pusako, 2(1), 159164.

Lusiana, D., \& Setyaningsih, E. (2020). Pengaruh Pembelajaran Berbasis Masalah Dengan Strategi Think Talk Write Terhadap Kemampuan Representasi Matematis Dan Self Efficacy Siswa. AlphaMath: Journal of Mathematics Education, 4(2), 23. https://doi.org/10.30595/alphamath.v4i2.7358

Mahmudah, S. R. (2020). Pengaruh Pembelajaran Daring terhadap Psikologis Siswa Terdampak Social Distancing Akibat Covid 19. Jurnal Al-Mau'izhoh, 2(2), 1-14.

Mulyana, A., Senajaya, A. J., \& Ismunandar, D. (2021). INDIKATOR-INDIKATOR KECEMASAN BELAJAR MATEMATIKA DARING DI ERA PANDEMIK COVID-19 MENURUT PERSPEKTIF SISWA SMA KELAS X. Proximal: Jurnal Penelitian Matematika Dan Pendidikan Matematika, 4(1), 14-22. 
Noor, F., \& Ranti, M. G. (2019). Hubungan antara kemampuan berpikir kritis dengan kemampuan komunikasi matematis siswa SMP pada pembelajaran matematika. Math Didactic: Jurnal Pendidikan Matematika, 5(1), 75-82.

Nurazizah, S., \& Nurjaman, A. (2018). Analisis Hubungan Self Efficacy Terhadap Kemampuan Berpikir Kritis Matematis Siswa Pada Materi Lingkaran. JPMI (Jurnal Pembelajaran Matematika Inovatif), 1(3), 361. https://doi.org/10.22460/jpmi.v1i3.p361-370

Nursyahidah, F., \& Albab, I. U. (2017). Investigating student difficulties on integral calculus based on critical thinking aspects. Jurnal Riset Pendidikan Matematika, 4(2), 211. https://doi.org/10.21831/jrpm.v4i2.15507

Prastyo, H. (2020). Kemampuan Matematika Siswa Indonesia Berdasarkan TIMSS. Jurnal Padegogik, 3(2), 111-117. Retrieved from https://doi.org/10.35974/jpd.v3i2.2367

Prasojo, B. H., \& Ariyanti, N. (2017). KEMAMPUAN BERPIKIR KRITIS MAHASISWA MANAJEMEN UMSIDA DALAM MEMECAHKAN MASALAH MATEMATIKA BISNIS. Buana Matematika: Jurnal Ilmiah Matematika dan Pendidikan Matematika, 7(2), 61-68.

Puspaningtyas, N. D. (2019). Berpikir Lateral Siswa SD dalam Pembelajaran Matematika. Mathema Journal, 1(1), 24-30.

Rahayu, N., \& Alyani, F. (2020). Kemampuan Berpikir Kritis Matematis Ditinjau Dari Adversity Quotient. Prima: Jurnal Pendidikan Matematika, 4(2), 121-136.Riyanto, O. R., Waluya, S. B., \& Mariani, S. (2019). Mathematics Critical Thinking Reviewed from Self-efficacy and Motivation of Learning in Arias Learning. Journal of Primary Education, 8(5), 243-250.

Sari, M. (2020). NATURAL SCIENCE : Jurnal Penelitian Bidang IPA dan Pendidikan IPA, ISSN : $2715-$ 470X ( Online ), 2477 - 6181 ( Cetak ) Penelitian Kepustakaan ( Library Research ) dalam Penelitian Pendidikan IPA, 6(1), 41-53.

Sari, T. T. (2020). Self-Efficacy dan Dukungan Keluarga Dalam Keberhasilan Belajar Dari Rumah di Masa Pandemi Covid-19. Education Journal : Journal Educational Research and Development, 4(2), 127136. https://doi.org/10.31537/ej.v4i2.346

Schleicher, A. (2019). PISA 2018: Insights and Interpretations. OECD Publishing.

Suharna, H., \& Abdullah, N. H. (2020). Kemampuan Berpikir 4C Matematika dalam Pembelajaran di Masa Covid-19 Terutama Di Era New Normal. Delta-Pi: Jurnal Matematika dan Pendidikan Matematika, 9(2).

Sulaiman, N. N., \& Purwoko, B. (2021). HUBUNGAN ANTARA SELF EFFICACY DAN MOTIVASI BELAJAR DENGAN KEMANDIRIAN BELAJAR SISWA SMA NEGERI 1 PURI MOJOKERTO SELAMA PANDEMI COVID-19. Jurnal BK UNESA, 12(2).

Suryaningsih, I., \& Rahim, R. A. (2019). Efektivitas Pelatihan Efikasi Diri dalam Meningkatkan Motivasi Belajar Siswa Kelas X SMA Insan Cendekia Syech Yusuf Kab. Gowa. Equals, 2(2), 85-91.

Thomson, S., Wernert, N., O'grady, E., \& Rodrigues, S. (2017). Reporting Australia's results. Retrieved from www.acer.edu.au

Tresnawati, T., Hidayat, W., \& Rohaeti, E. E. (2017). Kemampuan Berpikir Kritis Matematis Dan Kepercayaan Diri Siswa Sma. Symmetry: Pasundan Journal of Research in Mathematics Learning and Education, 2, 116-122. https://doi.org/10.23969/symmetry.v2i2.616

Ulfa, M. (2019). Strategi Preview, Question, Read, Reflect, Recite, Review (PQ4R) Pada Pemahaman Konsep Matematika. Mathema Journal, 1(1), 48-55.

Utami, Y. P., Alan, D., Cahyono, D., \& Indonesia, U. T. (2020). Studi at Home : Analisis Kesulitan Belajar Matematika pada Proses Pemjbelajaran Daring. Jurnal Ilmiah Matematika Realistik (JI-MR), 1(1), 20-26. Retrieved from http://jim.teknokrat.ac.id/index.php/pendidikanmatematika/article/view/252/84

Wilfridus, Y., Tupen, S. N., \& Mei, M. F. (2021). IDENTIFIKASI PEMBELAJARAN MATEMATIKA DIMASA PANDEMI COVID-19 PADA SMP NEGERI SOKORIA. JUPIKA: JURNAL PENDIDIKAN MATEMATIKA, 4(1), 1-10. 